\title{
Trophic specializations of damselfishes are tightly associated with reef habitats and social behaviours
}

\author{
Laura Gajdzik $^{1}$ - Eric Parmentier ${ }^{1} \cdot$ Nicolas Sturaro $^{2} \cdot$ Bruno Frédérich $^{1,2}$
}

Received: 19 August 2016 / Accepted: 19 October 2016

(C) Springer-Verlag Berlin Heidelberg 2016

\begin{abstract}
Despite the increasing need to understand factors shaping community assembly, few studies have simultaneously explored the influence of niche-based and phylogenetic processes. Here, we investigate the relationships between diet, habitat and social behaviour in damselfishes (Pomacentridae) collected in 2014 at Moorea Island $\left(17^{\circ} 30^{\prime} \mathrm{S}, 149^{\circ} 50^{\prime} \mathrm{W}\right)$, French Polynesia. Isotope ratios of carbon and nitrogen, in association with stomach contents, delineate three trophic groups: pelagic feeders consuming zooplankton, benthic feeders mainly grazing on algae and an intermediate group feeding on prey from the whole bentho-pelagic compartment. Sulphur isotope ratios indicate segregation between species of the outer reef mostly depending on oceanic input of zooplankton and the lagoonal species relying on locally produced resources or even on terrestrial supply. We demonstrate a tight association between dietary specializations, habitat characteristics and social behaviours, and these correlations are further confirmed by integrating the phylogeny of Pomacentridae. We also provide evidence of phylogenetic conservatism for
\end{abstract}

Responsible Editor: K.D. Clements.

Reviewed by Undisclosed experts.

Electronic supplementary material The online version of this article (doi:10.1007/s00227-016-3020-x) contains supplementary material, which is available to authorized users.

Laura Gajdzik

laura.gajdzik@ulg.ac.be

1 Laboratory of Functional and Evolutionary Morphology, AFFISH Research Center, University of Liège, B6C, Sart Tilman, 4000 Liège, Belgium

2 Laboratory of Oceanology, MARE Centre, University of Liège, B6C, Sart Tilman, 4000 Liège, Belgium the stomach content and the habitat-behaviour characters. However, the isotopic trait is evolutionarily more labile probably because it thoroughly depicts the ecological niche of species. To summarize, pelagic feeders (mainly from the Chrominae) usually form shoals in areas close to the open ocean at a maximum depth of $20 \mathrm{~m}$. Benthic feeders (well represented in the Stegastinae) are ubiquitous, solitary and mostly territorial species found at various depths. The intermediate group includes gregarious species from three subfamilies that forage in the lagoon usually above $12 \mathrm{~m}$ depth. Overall, we give insight into processes that have structured the damselfish community in Moorea.

\section{Introduction}

Coral reefs are highly productive and structurally complex environments that have promoted diversification of marine teleost fishes (Alfaro et al. 2007; Price et al. 2011). Indeed, they house a wide array of fishes where niche partitioning may be viewed as one of the key factors in the course of their diversification. These resulting high levels of ecological diversity have allowed the stable co-occurrence of similar species (Schoener 1974; Colwell and Fuentes 1975). Within that context, unravelling the multiplicity of factors acting upon the fish community represents a key challenge to be tackled. Community assembly is governed by niche-based processes (including habitat filtering and competitive exclusion) and by the phylogenetic relatedness among organisms (Cavender-Bares et al. 2009; Ndiribe et al. 2013). Nowadays, the use of phylogenetic information has become more widespread in ecological studies focusing on the structure of organisms (Losos et al. 2003) because it gives valuable insight into the pattern of phylogenetic niche conservatism (PNC). This pattern is defined 
as the tendency of lineages to retain their niche-related traits through speciation events and over macroevolutionary time (Crisp and Cook 2012), with a corollary that closely related species exhibit higher ecological similarities than expected based on their phylogenetic relationships (Webb et al. 2002; Losos 2008).

Niche-based processes include the study of feeding ecology of species and populations, which is usually evaluated with two methods. (1) Stomach content analysis is widely recognized as a standard technique to determine the diet but only displays the most recent meal (Hyslop 1980). (2) Stable isotope ratios of carbon $\left(\mathrm{C}^{13} / \mathrm{C}^{12}\right.$, hereafter noted as $\left.\delta^{13} \mathrm{C}\right)$ and nitrogen $\left(\mathrm{N}^{15} / \mathrm{N}^{14}\right.$, noted as $\left.\delta^{15} \mathrm{~N}\right)$ are a classical approach in trophic ecology, allowing time-integrated studies of animal diet or niche assessment (Post 2002; Newsome et al. 2007). More recently, the stable isotope ratio of sulphur $\left(\mathrm{S}^{34} / \mathrm{S}^{32}\right.$ or $\left.\delta^{34} \mathrm{~S}\right)$ has been used as an additional tracer of food sources (McCutchan et al. 2003; Connolly et al. 2004; Moreno et al. 2010). The high variation in $\delta^{34} \mathrm{~S}$ values between seawater $(\sim 22.9 \%)$ and sediments $(\sim 1 \%)$ helps to discriminate the origins of prey and locations of feeding grounds within the marine environment (Kharlamenko et al. 2001; Fry et al. 2008; Mittermayr et al. 2014). Even though $\delta^{34} \mathrm{~S}$ is extremely helpful to disentangle trophic interactions among organisms, no study has integrated this element to investigate the ecology of coral reef fishes. Other information regarding habitat preferences and social behaviours, needed to appraise all aspects of ecological niches, are commonly collected by visual observations (e.g. Lecchini and Galzin 2005).

Many studies in diverse taxa (e.g. insular terrestrial organisms and marine invertebrates) used the historic relationships among species to evaluate PNC patterns of various ecological traits (e.g. Knouft et al. 2006; Roy et al. 2009; Cooper et al. 2011). The study of phylogenetic signal constitutes one method to detect PNC and greatly varies among traits (Blomberg et al. 2003; Losos 2008). The niche-complementarity hypothesis predicts that species similar along one dimension of the niche must differ along other axes to support their coexistence (Schoener 1974). However, in some clades, there is not always tangible evidence sustaining that prediction because interactions among species may be responsible for a non-random distribution of species within the ecological space. Consequently, distantly related species might share more in common than closely related ones (Losos et al. 2003). To date, there is an overall scarcity of documented cases investigating the interactions between feeding strategy, habitat and behaviour when taking into account phylogenetic information, especially in coral reef fishes.

The Pomacentridae family (damselfishes), which groups 399 species (Eschmeyer et al. 2016), represents a suitable system to investigate factors shaping the community in reef ecosystems. Interestingly, damselfishes show a great diversity of habitats (Ormond et al. 1996; Lecchini and Galzin 2005) and various social behaviours (Fishelson 1998). Furthermore, recent studies have established a firm phylogenetic framework for their radiation (Cooper et al. 2009; Cooper and Santini 2016) and revealed that damselfishes have iteratively evolved along three main feeding strategies, i.e. pelagic feeders, benthic foragers and an intermediate group (Cooper and Westneat 2009; Frédérich et al. 2013, 2016a, b). Several field observations also suggested a strong link between diet, habitat use and social behaviour in Pomacentridae (Emery 1973; Frédérich et al. 2009), but they only constitute a qualitative assumption. The analysis of quantitative data is therefore needed to formally establish these correlations.

The aim of the present study is to examine the congruence between diet, habitat and social behaviour in damselfishes (Pomacentridae) from coral reefs at Moorea Island, French Polynesia. We first explore the niche partitioning of Pomacentridae through an approach combining three stable isotope ratios $\left(\delta^{15} \mathrm{~N}, \delta^{13} \mathrm{C}\right.$ and $\left.\delta^{34} \mathrm{~S}\right)$ and the analysis of stomach contents. Then, we describe the habitat and social behaviour of each species. We investigate whether there is a correlation between dietary and habitat-behaviour characteristics at the present time. We further explore the relationships between these ecological traits across the phylogeny of Pomacentridae and test whether these traits show a phylogenetic signal. Overall, our data provide a better understanding of the processes ruling the damselfish community assembly and the causes of its structure.

\section{Materials and methods}

\section{Sampling and collection of ecological data}

The sampling campaign was carried out from April to July 2014 in Moorea, an island located in the South Pacific $\left(17^{\circ} 30^{\prime} \mathrm{S}, 149^{\circ} 50^{\prime} \mathrm{W}\right.$; French Polynesia). The lagoon in Moorea comprises coral patches found in between sand banks and a fringing reef shaped as a wall. The barrier reef includes the outer reef slope and the reef crest and is hereafter referred as the outer reef. Sampling occurred at Opunohu Bay located on the north side of Moorea but also in front of Haapiti in south-west part of the island (Fig. 1; Table 1). Damselfishes-belonging to four subfamilies and 17 species-were either caught with a speargun or by the use of clove oil across the whole reef at Opunohu Bay (Table 1). Four species (Chromis iomelas, Chromis margaritifer, Dascyllus flavicaudus and Dascyllus trimaculatus) were ubiquitous with individuals foraging in the two main reef zones (the lagoon and the outer reef), which were treated separately during statistical analyses. Furthermore, 


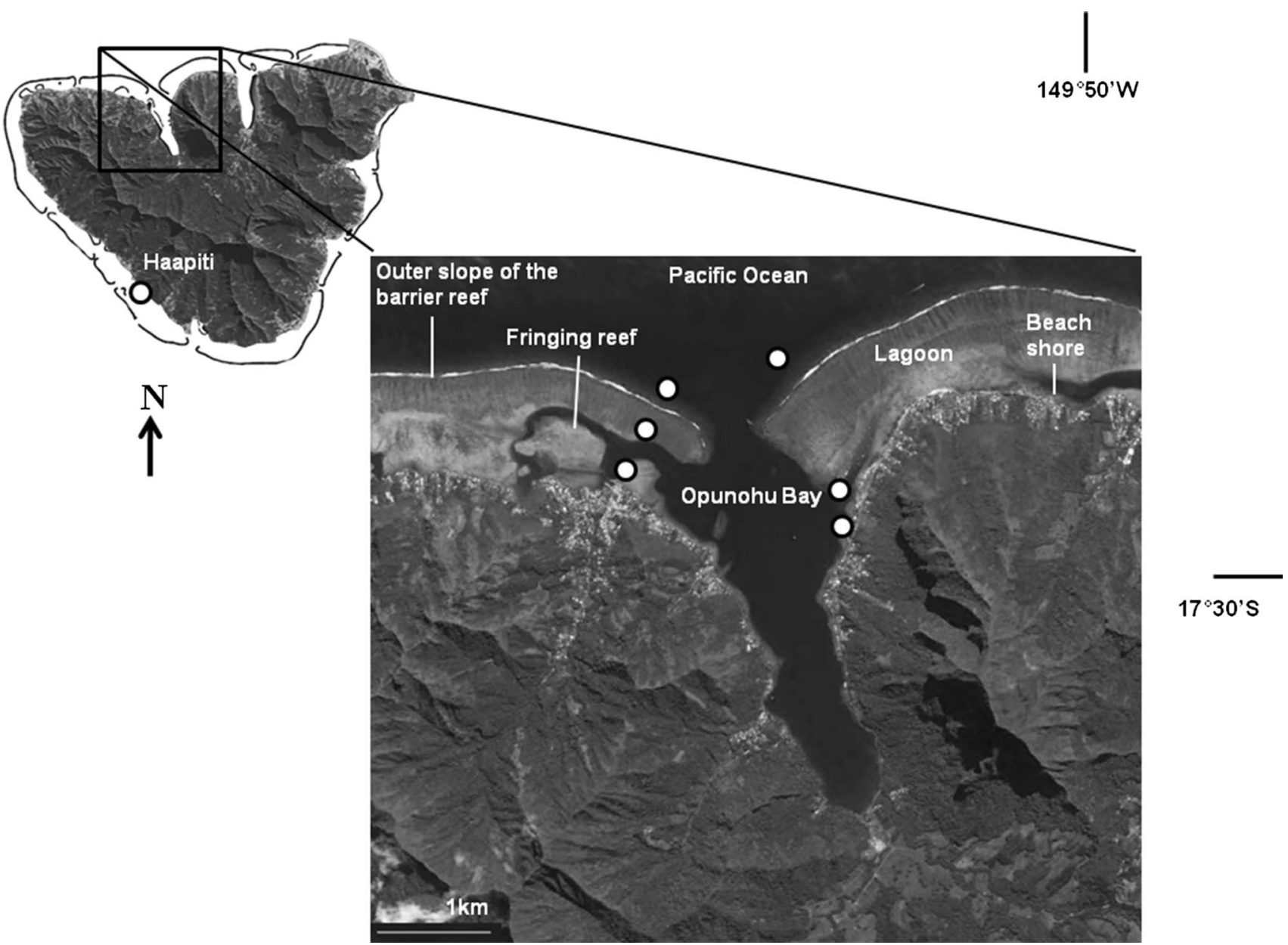

Fig. 1 Map of Moorea (French Polynesia) with sampling sites indicated by white-filled circles. At Opunohu Bay, sampling occurred in coral patches along the beach shore, in the fringing reef and also on

individuals of Abudefduf septemfasciatus were collected in two distinct reefs, i.e. in the Opunohu Bay and in front of Haapiti (Fig. 1). Sampling for A. septemfasciatus was only conducted along the beach at both reef locations and each population was treated separately when performing statistical tests.

Fishes were euthanized by an overdose of MS-222 (tricaine-methanosulfanate) and placed on ice in cool boxes when brought back to the boat. The standard length of each fish individual was measured to the nearest millimetre using a vernier caliper (Table 1). The entire digestive tract was removed and conserved in $70 \%$ ethanol for stomach content analysis. Tissue samples of epaxial muscles were cut off and placed in a drying oven for further isotope analyses. Various food sources and primary producers (e.g. red or brown algae, benthic invertebrates and zooplankton) were taken at the same locations where fishes were collected (in the lagoon and the outer reef). Specifically, zooplankton the outer slope of the barrier reef (the outer reef). Another site was located in front of Haapiti where one species was collected along the beach shore

was sampled with a $250-\mu \mathrm{m}$ net towing at $2 \mathrm{~m}$ depth above reefs. This sampling method was replicated three times and is similar to the technique used to study the niche partitioning of damselfishes in Madagascar (Frédérich et al. 2009).

\section{Stomach content analysis}

Prey items were identified, sorted to class or order levels and counted under a binocular microscope Leica MS-5. Food sources were classified into six categories reflecting different ecological types of prey: zooplankton, benthic algae, vagile invertebrates, rubble, benthic egg and insect. Zooplankton included copepods (i.e. Poecilostomatoida, Calanoida, Harpacticoida), pelagic eggs of fishes, nauplii and zoea larvae. Benthic algae grouped filamentous and macroalgae (brown and red algae). Vagile invertebrates comprised small crabs, amphipods, isopods, gastropods, polychaetes and platyhelminthes. Rubble was also found 
Table 1 Damselfish species caught in Moorea in 2014 with indication of the number of individuals (ind.) used for each method: stomach content (SC) and stable isotope (SI) analyses

\begin{tabular}{|c|c|c|c|c|c|c|c|}
\hline Damselfish species & Abbreviations & Reef location & Reef zone & $\begin{array}{l}\text { Standard } \\
\text { length }(\mathrm{mm})\end{array}$ & $\begin{array}{l}\text { Nbr. ind. } \\
\text { SC }\end{array}$ & $\begin{array}{l}\text { Nbr. empty } \\
\text { stomachs }\end{array}$ & $\begin{array}{l}\text { Nbr. ind. } \\
\text { SI }\end{array}$ \\
\hline Abudefduf septemfasciatus & A. sept & $\mathrm{H} \& \mathrm{O}$ & Lagoon & $103.5-151.6$ & 16 & 1 & 17 \\
\hline Abudefduf sexfasciatus & A. $\operatorname{sexf}$ & $\mathrm{O}$ & Lagoon & $53.2-94.7$ & 7 & 0 & 6 \\
\hline Chromis acares & C. aca & $\mathrm{O}$ & Outer reef & $31.6-36.5$ & 12 & 5 & 14 \\
\hline Chromis iomelas & C. iom & $\mathrm{O}$ & Both & $35.5-47.0$ & 11 & 2 & 12 \\
\hline Chromis margaritifer & C. marg & $\mathrm{O}$ & Both & $38.2-59.9$ & 18 & 0 & 13 \\
\hline Chromis vanderbilti & C. vand & $\mathrm{O}$ & Outer reef & $32.3-40.7$ & 19 & 1 & 15 \\
\hline Chromis viridis & C. vir & $\mathrm{O}$ & Lagoon & $31.3-54.8$ & 7 & 4 & 11 \\
\hline Chrysiptera brownriggii & Ch. brown & $\mathrm{O}$ & Lagoon & $30.2-52.2$ & 16 & 4 & 20 \\
\hline Dascyllus aruanus & D. arua & $\mathrm{O}$ & Lagoon & $29.8-47.3$ & 12 & 0 & 6 \\
\hline Dascyllus flavicaudus & D. flavi & $\mathrm{O}$ & Both & $29.1-75.1$ & 12 & 2 & 12 \\
\hline Dascyllus trimaculatus & D. trima & $\mathrm{O}$ & Both & $82.6-97.3$ & 5 & 2 & 7 \\
\hline Plectroglyphidodon johnstonianus & P. johnst & $\mathrm{O}$ & Outer reef & $37.1-58.4$ & 11 & 3 & 17 \\
\hline Plectroglyphidodon lacrymatus & P. lacry & $\mathrm{O}$ & Outer reef & $33.8-66.2$ & 17 & 1 & 18 \\
\hline Pomacentrus pavo & Po. pavo & $\mathrm{O}$ & Lagoon & $33.3-72.7$ & 20 & 1 & 20 \\
\hline Pomachromis fuscidorsalis & Pom. fusc & $\mathrm{O}$ & Outer reef & $38.8-54.4$ & 15 & 6 & 21 \\
\hline Stegastes fasciolatus & S. fascio & $\mathrm{O}$ & Outer reef & $42.8-62.9$ & 16 & 3 & 14 \\
\hline Stegastes nigricans & S. nigri & $\mathrm{O}$ & Lagoon & $70.3-111.8$ & 24 & 0 & 17 \\
\hline
\end{tabular}

The reef location indicates where damselfish species were collected either in front of Haapiti $(\mathrm{H})$ in the south-west part of Moorea or in the northern part in Opunohu Bay (O). The reef zone specifies the local sampling sites: the lagoon, the outer reef (outer slope of the barrier reef) or both

in stomachs; its origin assumed to be either rocks or corals. Benthic egg meant eggs from all types of organisms (e.g. fish or invertebrates) deposited on the substrate. Finally, the insect group included two orders of Hexapoda: Hymenoptera and Diptera. The number of items in each food category was recorded and expressed as a percentage to the total number of items for each individual stomach (Hyslop 1980).

\section{Stable isotope analysis}

Samples of fish muscle tissues and potential food sources were dried for $48 \mathrm{~h}$ at $60{ }^{\circ} \mathrm{C}$ and ground into a homogenous fine powder using a mortar and a pestle. All samples of food sources containing carbonates (e.g. algae samples and zooplankton) were acidified with $\mathrm{HCl}$ vapours (37\%) for $24 \mathrm{~h}$ in order to remove inorganic carbon, which is not related to diet but a source of bias in the analysis of carbon stable isotope ratios (Mateo et al. 2008). Stable isotope ratios of carbon $\left({ }^{13} \mathrm{C} /{ }^{12} \mathrm{C}\right)$, nitrogen $\left({ }^{15} \mathrm{~N} /{ }^{14} \mathrm{~N}\right)$ and sulphur $\left({ }^{34} \mathrm{~S} /{ }^{32} \mathrm{~S}\right)$ were measured at the Laboratory of Oceanology of the University of Liège, using an isotope ratio mass spectrometer (IsoPrime 100, Isoprime, UK) coupled in continuous flow to an elemental analyser (vario MICRO cube, Elementar, Germany). Isotope ratios were conventionally expressed as $\delta$ values in \%o relative to the vPDB (Vienna Pee Dee Belemnite) for carbon (C), atmospheric $\mathrm{N}_{2}$ for nitrogen (N) and Canon Diablo troilite (CDT) for sulphur (S) (Coplen 2011). Certified reference materials from the International Atomic Energy Agency (IAEA, Vienna, Austria) used were sucrose (IAEA-C6, $\delta^{13} \mathrm{C}=-10.8 \pm 0.5 \%$; mean \pm standard deviation), ammonium sulphate (IAEA$\mathrm{N}_{2}, \delta^{15} \mathrm{~N}=20.3 \pm 0.2 \%$ ) and silver sulphide (IAEA$\mathrm{S} 1, \delta^{34} \mathrm{~S}=-0.3 \pm 0.3 \%$ ). Hundreds of replicate assays of internal laboratory standards (powder of sulfanilic acid) indicate measurement errors (standard deviation) of $\pm 0.2 \%$ or for $\delta^{13} \mathrm{C}, \pm 0.3 \%$ or for $\delta^{15} \mathrm{~N}$ and $\pm 0.5 \%$ o for $\delta^{34} \mathrm{~S}$.

\section{Description of habitat and social behaviour}

The ecology of each studied damselfish species was recorded during underwater visual surveys by one observer. Observations were conducted while scuba diving or snorkelling for 50-60 $\mathrm{min}$ at the same location where fishes were caught, i.e. along the beach shore, in the fringing reef and the outer reef (Fig. 1). In order to capture potential variability of behaviours, duplicate observations at each sampling site were done at the same time, between 2 p.m. and 5 p.m. Our dataset was also completed using information from the literature (Fishelson 1998; Hattori and Casadevall 2016; Pratchett et al. 2016). The habitats and social behaviours for 17 species were summarized into five categorical traits (Table 2). (1) The location of fishes along 
the coral reef ecosystem was distributed in three categories: "lagoon", "outer reef" or in "both" parts. (2) Microhabitat requirements were coded as "sandy areas" for fishes found between coral patches in the lagoon, "dead corals/rocks", "corals (O)" for damselfishes having obligated relationships with their live coral hosts and "corals (F)" for species having facultative relationships with corals which they use infrequently or opportunistically (Pratchett et al. 2016). (3) The depth range was the minimal and maximal depths expressed in metres (Pratchett et al. 2016). (4) The group type and territoriality were coded together: group type consisted of seven categories, whereas territoriality was simply defined as "yes" or "no". The classification for the group size was: "solitary" when species were exclusively found alone, "solitary or pairing", "small social groups" when a size-ordered dominance hierarchy existed among fishes, shoals (i.e. aggregations of individuals swimming in different directions): "small shoals" (with 3-10 individuals), "medium shoals" (with 11-20 individuals) or "large shoals" (with $>21$ individuals) and finally "large schools" (>21 individuals foraging around diverse shelters and swimming in a coordinate manner towards the same direction) (Fishelson 1998; Hattori and Casadevall 2016). (5) The water column position of fishes, defined as its average swimming distance from the substrate, was coded using three main categories: "OS" for species staying all the time close to the bottom, "CS" for species commonly swimming at an approximate distance of 0.5-1.0 $\mathrm{m}$ from the substrate and "FR" for damselfishes freely swimming throughout the water column without being restricted to one particular area.

\section{Statistical analyses and phylogenetic comparative methods}

\section{Stomach content analysis}

Stomach content data were analysed using the PRIMER software version 6.1.6 (Plymouth Routines in Multivariate Ecological Research Ltd, UK; Clarke 1993). The stomach data of each fish individual were treated as a sampling unit. These data were firstly standardized before creating a Bray-Curtis matrix to quantify the compositional dissimilarity. An analysis of similarity (ANOSIM) was then performed to test similarities among stomach contents grouped per species.

\section{Stable isotope analysis}

Food sources Differences among food sources were only investigated for zooplankton because it was the only food source with replicates. A $t$ test was conducted in $\mathrm{R}$ version 3.2.4 (R Core Team 2016) because data were normally distributed and variances homogeneous.
Damselfishes We explored our CNS isotopic dataset of damselfishes with a principal component analysis (PCA) using the PRIMER software version 6.1.6. (Clarke 1993). PCA consists of rotating the axes such that as much variability as possible is accounted on consecutive orthogonal principal components (PCs) depicting a multidimensional space (Davis 1986). This space was thus reduced to two dimensions as the first two PCs cumulated $92.8 \%$ of the total variation (Supplementary Fig. S1). The eigenvectors of $\delta^{13} \mathrm{C}$ and $\delta^{15} \mathrm{~N}$ were similar in magnitude and direction along both PC axes (Supplementary Fig. S1), showing that these two isotope ratios were strongly correlated among species. Since we multiplied our $\delta^{13} \mathrm{C}$ data by -1 in the PCA, the similar $\delta^{13} \mathrm{C}$ and $\delta^{15} \mathrm{~N}$ eigenvectors revealed that the lower the $\delta^{13} \mathrm{C}$ values, the higher were the $\delta^{15} \mathrm{~N}$ values. Conversely, in the PC1-2 space, the $\delta^{34} \mathrm{~S}$ eigenvector appeared orthogonal to the $\delta^{13} \mathrm{C}$ and $\delta^{15} \mathrm{~N}$ eigenvectors (Supplementary Fig. S1), indicating that $\delta^{34} \mathrm{~S}$ represented independent information regarding the segregation of species within the isotopic space. Based on these findings, we conducted a second PCA using only $\delta^{13} \mathrm{C}$ and $\delta^{15} \mathrm{~N}$ values. This allowed us to describe most $(89.9 \%)$ of the variance in $\delta^{13} \mathrm{C}$ and $\delta^{15} \mathrm{~N}$ values with a single PC axis (hereafter referred as $\mathrm{PC}_{\mathrm{C}-\mathrm{N}}$ ). Differences among species were thus explored using these $\mathrm{PC}_{\mathrm{C}-\mathrm{N}}$ scores and the $\delta^{34} \mathrm{~S}$ values, separately. Kruskal-Wallis tests (kruskal.test) were conducted with the $\mathrm{R}$ package lattice version 0.2-33 because assumptions of normality and homogeneity of variances were not met. When significant differences $(P \leq 0.05)$ were found, a post hoc test (kruskalmc) was conducted for multiple pairwise comparisons among species with the $\mathrm{R}$ package pgirmess version 1.6.4. Furthermore, a hierarchical clustering (dendrogram) was also constructed with PRIMER software version 6.1.6. (Clarke 1993) to further infer similarities among species.

\section{Relationships between diet, habitat and social behaviour}

The relationship between trophic data (defined either by stomach content (SC) or by stable isotopes (SI)) and habitat-behaviour information was first tested without phylogenetic information and then by integrating the evolutionary history of damselfishes. For both tests, the first step was to transform data by creating a dissimilarity matrix for each dataset: SC, SI and habitat-behaviour. The Bray-Curtis distance was used for both SC and SI databases given the continuous values and was performed with the $\mathrm{R}$ package ecodist version 1.2.9 (Goslee and Urban 2007). As the habitat-behaviour dataset contains only discrete values, we applied the Gower distance using the $\mathrm{R}$ package cluster version 2.0.3 (Gower 1971; Maechler et al. 2015). Then a multidimensional space with a principal coordinates analysis (Pcoa) was computed on each dissimilarity matrix 
with the R package ape version 3.4 (Paradis et al. 2004). We applied the Cailliez correction, which consists of adding a constant value to the original distances in the matrix, in order to keep only positive values (Cailliez 1983; Legendre and Legendre 1998). Euclidean distances in the twodimensional (2D) space were significantly correlated with initial Bray-Curtis distances for both SC and SI dissimilarity matrices, and with initial Gower distances for habitatbehaviour dissimilarity matrix (Mantel test with $10^{5}$ iterations, $r=0.92 ; P<0.001 ; r=0.97, P<0.001 ; r=0.99$, $P<0.001$, respectively). This step ensures that most of the variability was robustly captured in each $2 \mathrm{D}$ space. For accuracy, we also tested whether adding one axis increased the quality of the multidimensional space but it did not. The coordinates in the 2D space (Pcoa 1 and Pcoa 2) for each matrix (i.e. the trophic data matrix, either with $\mathrm{SC}$ or with SI, and the habitat-behaviour matrix) have been used for the following tests. This data transformation into multidimensional spaces is conceptually similar to the framework developed by functional ecologists in order to quantify functional diversity (e.g. Mouillot et al. 2014; Maire et al. 2015).

The degree of association between the 2D space of trophic data and the 2D space of habitat-behaviour was assessed using a standard multivariate regression based on Procrustes distances with the function procD.lm (Adams and Otárola-Castillo 2013). Then, we performed another Procrustes distance-based method for evaluating regression linear models for the 2D space with phylogenetic information. This approach (D-PGLS) was used to test for independent relationships between trophic and habitatbehaviour data under a Brownian motion model of evolution (Adams 2014b; Collyer et al. 2015). This test was done with the function procD.pgls. Both analyses (procD.lm and procD.pgls) were performed with $10^{6}$ iterations in the $\mathrm{R}$ package geomorph version 3.0.1 (Adams and Otárola-Castillo 2013).

\section{Phylogenetic signals of ecological traits}

We also explored whether trophic data and habitat-behaviour traits showed a phylogenetic signal, which is defined as the statistical dependence among species trait values due to their phylogenetic relatedness (Revell et al. 2008). This test was applied on the 2D space of SC, SI and habitatbehaviour using the function physignal from the $\mathrm{R}$ package geomorph and performed with $10^{5}$ iterations (Adams and Otárola-Castillo 2013; Adams 2014a). The calculated $\mathrm{K}$ is a mathematical generalization of the Kappa statistic from Blomberg et al. (2003). A $K_{\text {mult }}>1$ means a stronger resemblance of species than expected under a Brownian motion model of evolution, whereas $K_{\text {mult }}<1$ indicates a greater malleability of traits.
The molecular time-calibrated and multigene phylogeny of Pomacentridae from Frédérich et al. (2013) was pruned to match the species in the dataset and provided an estimate of the evolutionary relationships among taxa. Almost all the studied species were found in that phylogeny, except for Plectroglyphidodon johnstonianus, Pomachromis fuscidorsalis and Chromis acares. Plectroglyphidodon johnstonianus and $P$. fuscidorsalis present very similar morphologies and colour patterns to $P$. dickii and $P$. richardsonii, for which molecular data are available. Thus, the phyletic position of $P$. dickii and $P$. richardsonii was used for $P$. johnstonianus and P. fuscidorsalis, respectively. Then, we applied the function locate.yeti in the R package phytools version 0.5-20 to place $C$. acares in the phylogeny of damselfishes using continuous traits (Revell 2012; Revell et al. 2015). We used meristic data from Allen (1991) which were then transformed into a multidimensional space following the same steps as for the habitat-behaviour trait (see above). We used the coordinates from the first five Pcoas into the function locate.yeti (Mantel test results with $10^{5}$ iterations: $\left.r=0.88 ; P<0.001\right)$. We also tested whether adding one dimension improved the quality of the multidimensional space but it was not the case. The timecalibrated phylogeny including the 17 studied species from Moorea was used in the D-PGLS analysis and in the tests for phylogenetic signal.

\section{Results}

\section{Trophic diversity}

\section{Stomach contents}

The stomachs of 273 individuals were analysed but 35 of them were empty (Table 1). In every species, stomachs were partially filled with unidentifiable items. The origin of this amorphous material was uncertain, and thus this item was excluded from all statistical analyses. For the four ubiquitous species, we found no significant differences in stomach contents between the lagoonal individuals and the ones caught in the outer reef (Supplementary Table S1). No significant differences appeared between the population of A. septemfasciatus from Opunohu Bay and the one from Haapiti. Overall, we found some significant differences in the stomach contents among the 17 species (ANOSIM global test, $R=0.501, P<0.001$ ), but some can be clustered together (pairwise comparison tests, $R>0.5$; Fig. 2; Supplementary Table S1). Cluster A comprises nine species (D. trimaculatus, C. iomelas, C. margaritifer, Chromis vanderbilti, Pomacentrus pavo, Chromis viridis, Pomachromis fuscidordalis, D. flavicaudus and Chromis acares) for which zooplankton contributed the most to their 


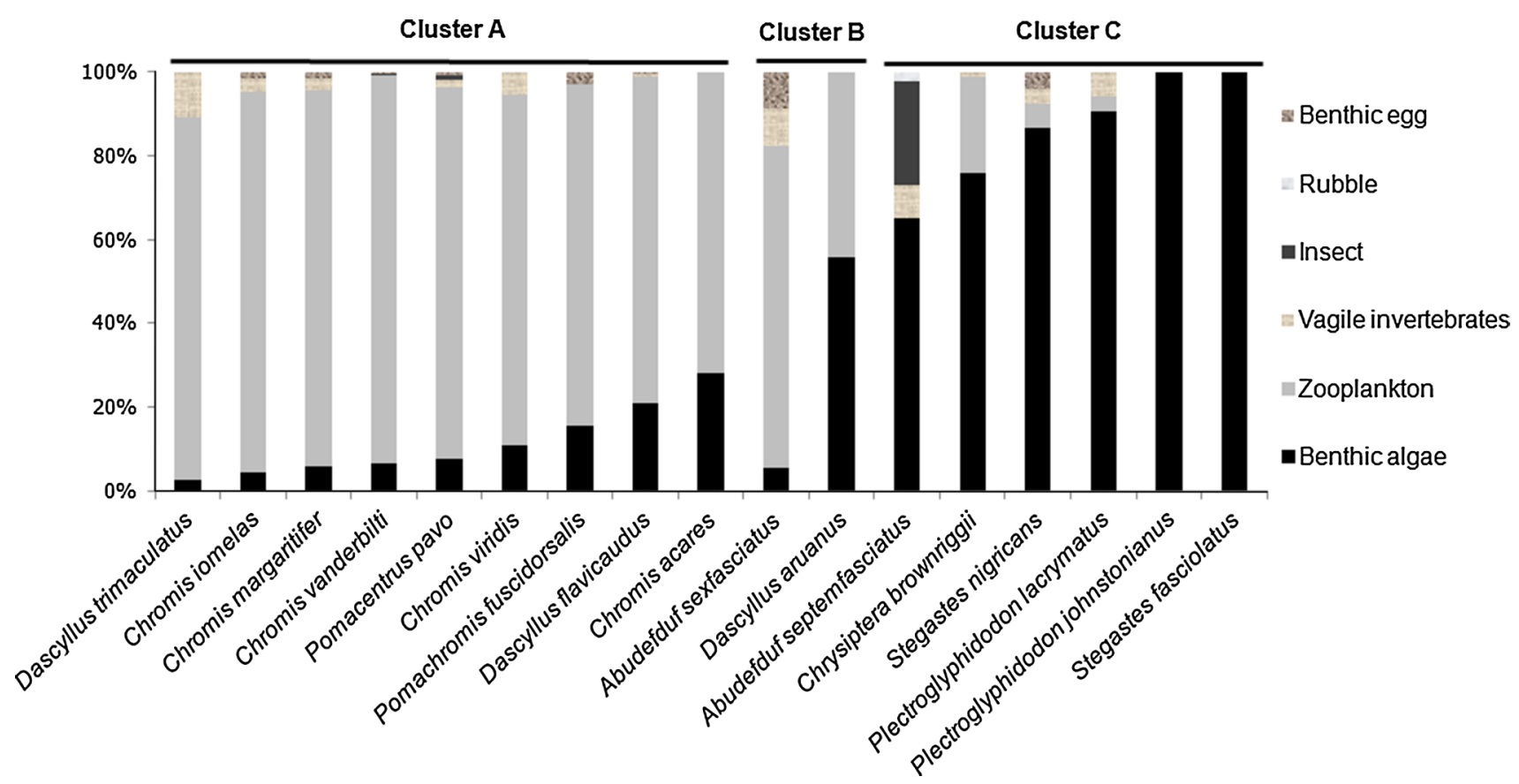

Fig. 2 Dietary compositions of the 17 damselfish species caught in Moorea in 2014. The six food categories are represented by different colour patterns. Clustering was performed with analysis of similarity (ANOSIM) on stomach content data

diet (71-91\%). Individuals of D. trimaculatus and C. viridis were partially feeding on vagile benthic invertebrates, respectively, 6 and 15\%. Abudefduf sexfasciatus and Dascyllus aruanus formed the second cluster (B). Zooplankton and benthic algae almost equally contributed to the diet of $D$. aruanus, whereas benthic food sources (algae, vagile invertebrates and benthic eggs) filled $23 \%$ of stomachs of A. sexfasciatus. Cluster $\mathrm{C}$ grouped A. septemfasciatus, Chrysiptera brownriggii, Stegastes nigricans, Plectroglyphidodon lacrymatus, Plectroglyphidodon johnstonianus and Stegastes fasciolatus for which stomachs were filled with $71-100 \%$ of benthic algae. Vagile invertebrates $(8 \%)$ were also found in A. septemfasciatus but insects filled $25 \%$ of their stomachs (Fig. 2).

\section{Stable isotopes}

The potential food sources displayed lower $\delta^{13} \mathrm{C}$ and $\delta^{15} \mathrm{~N}$ values than damselfishes (Fig. 3a), but their $\delta^{34} \mathrm{~S}$ values were within the same range as the ones $\delta^{34} \mathrm{~S}$ of fishes, except for red algae from the outer reef whose value was slightly higher (Fig. 3b). The algal sources from the lagoon had $\delta^{13} \mathrm{C}$ values varying between $-12 \%$ and $-10 \%$, between 4 and $5 \%$ o for $\delta^{15} \mathrm{~N}$ values. In contrast, red algae from the outer reef displayed lower $\delta^{13} \mathrm{C}$ values and higher $\delta^{15} \mathrm{~N}$ values. It should be noted that we sampled different types of algae in the outer reef but we only obtained isotope ratios for red algae. The values of vagile invertebrates from the lagoon were $-12.7 \%$ for $\delta^{13} \mathrm{C}$ and $6.0 \%$ for $\delta^{15} \mathrm{~N}$. Samples of zooplankton collected in the lagoon and in the outer reef showed similar values for $\delta^{15} \mathrm{~N}$ and $\delta^{34} \mathrm{~S}(t$ tests, $t_{3}=0.46, P>0.05$ and $\left.t_{3}=1.59, P>0.05\right)$, but their $\delta^{13} \mathrm{C}$ values were significantly different $\left(t\right.$ test, $t_{3}=-3.71$, $P<0.05)$. Overall, potential food sources displayed variation in $\delta^{13} \mathrm{C}$ values when comparing the two main reef zones. Zooplankton and algae showed less negative $\delta^{13} \mathrm{C}$ values in the lagoon than in the outer reef (Fig. 3a). However, $\delta^{34} \mathrm{~S}$ values $(17.7-19.8 \%$ ) of these food sources were found within a same range between reef zones (Fig. 3b).

Significant differences among damselfish species according to their $\mathrm{PC}_{\mathrm{C}-\mathrm{N}}$ scores were found (Kruskal-Wallis test, $\left.H_{20}=209.62, P<0.001\right)$. Post hoc tests showed three main groups of species (referred to as groups 1, 2, and 3; Supplementary Table S2), which are illustrated on the plot of $\delta^{15} \mathrm{~N}$ versus $\delta^{13} \mathrm{C}$ (Fig. 3a) and further supported by results of the dendrogram (Supplementary Fig. S2). Group 1 is composed of three species exclusively found in the outer reef $(C$. acares, $C$. vanderbilti and $P$. fuscidorsalis), individuals from the outer reef of the four ubiquitous species (C. iomelas, C. margaritifer, D. flavicaudus and D. trimaculatus) and also lagoonal individuals of $D$. trimaculatus. Group 2 is composed of nine species in total, including lagoonal individuals of three ubiquitous species $(C$. iomelas, C. margaritifer and D. flavicaudus), three species strictly from the outer reef $(P$. johnstonianus, $P$. lacrymatus and $S$. fasciolatus) and three species only foraging in 
Fig. 3 a Average ( \pm standard deviation, SD) $\delta^{15} \mathrm{~N}$ and $\delta^{13} \mathrm{C}$ values of the 17 damselfish species caught in Moorea in 2014. Clustering (Groups 1, 2 and 3) was based on multiple pairwise comparisons on $\mathrm{PC}_{\mathrm{C}-\mathrm{N}}$ scores of damselfishes. Grouping within the outer reef was shown with ${ }^{\mathrm{A}}$ and ${ }^{\mathrm{B}}$; whereas it was indicated with ${ }^{\mathrm{a}},{ }^{\mathrm{b}}$ and ${ }^{\mathrm{c}}$ in the lagoon. $\mathbf{b}$ Average $( \pm \mathrm{SD}) \delta^{34} \mathrm{~S}$ and $\delta^{13} \mathrm{C}$ values of the 17 damselfish species caught in Moorea in 2014. Clustering (Groups i, ii and iii) was based on multiple pairwise comparisons on $\delta^{34} \mathrm{~S}$ values of damselfishes. Species abbreviations are provided in Table 1. Four species (Chromis iomelas, Chromis margaritifer, Dascyllus flavicaus and Dascyllus trimaculatus) were ubiquitous with individuals foraging in the two main reef zones, i.e. the lagoon and the outer reef. One species (Abudefduf septemfasciatus) was caught in two distinct reef locations (in front of Haapiti and in Opunohu Bay). An upward-pointing triangle represents species caught in front of Haapiti, whereas a downwardpointing triangle indicates species collected in Opunohu Bay. White-filled triangles represent species caught in the lagoon, whereas black-filled triangles mean species gathered in the outer slope of the barrier reef (the outer reef). Food sources are represented by a diamond icon and were all collected in Opunohu Bay. The white-filled diamond refers to the lagoon, while the grey-filled diamond means that food sources were gathered in the outer reef
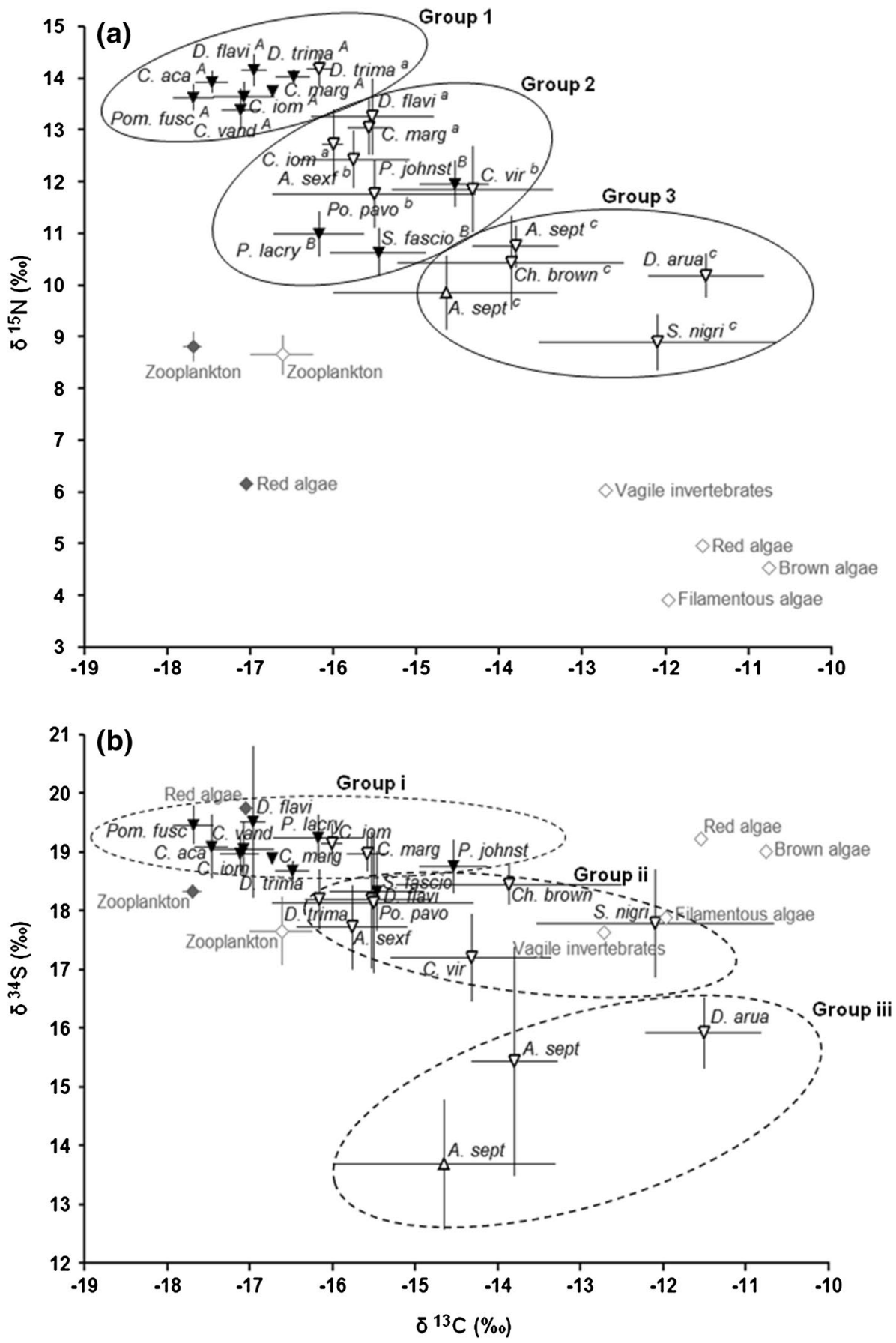

the lagoon (A. sexfasciatus, $C$. viridis and $P$. pavo). Group 3 consisted of four species only present in the lagoon: $A$. septemfasciatus from Opunohu and Haapiti, C. brownriggii, D. aruanus and $S$. nigricans. Furthermore, the variation in $\delta^{13} \mathrm{C}$ values of potential food sources might impact the trophic diversity of damselfishes along this isotopic axis. Therefore, we repeated statistical analyses on $\mathrm{PC}_{\mathrm{C}-\mathrm{N}}$ scores for each damselfish assemblage: the one from the outer reef and the one from the lagoon. Kruskal-Wallis test and multiple pairwise comparisons delineated two groups of species within the outer reef assemblage $\left(H_{8}=95.51\right.$, $P<0.001)$. The first group comprised seven species including Pomachromis sp., four Chromis and two Dascyllus spp. (Supplementary Table S3; Fig. 3a). The second group in the outer reef contained both species of Plectroglyphidodon and $S$. fasciolatus. In the lagoon, significant 
Table 2 Habitat and behavioural variables coded into five categories for each damselfish species caught in Moorea

\begin{tabular}{|c|c|c|c|c|c|}
\hline Damselfish species & Reef location & $\begin{array}{l}\text { Microhabitat } \\
\text { requirements }\end{array}$ & Depth $(m)^{\mathrm{a}}$ & $\begin{array}{l}\text { Group type \& } \\
\text { territoriality }, \mathrm{c}\end{array}$ & $\begin{array}{l}\text { Position in the } \\
\text { water column }\end{array}$ \\
\hline Abudefduf septemfasciatus & Lagoon & Sandy areas & $0-3$ & Solitary or pairing, No & FS \\
\hline Abudefduf sexfasciatus & Lagoon & Corals $(\mathrm{F})$ & $1-15$ & Small shoals, No & FS \\
\hline Chromis viridis & Lagoon & Corals $(\mathrm{O})$ & $1-12$ & Large schools, No & $\mathrm{CS}$ \\
\hline Chrysiptera brownriggii & Lagoon & Corals $(\mathrm{F})$ & $0-2$ & Solitary, No & $\mathrm{CS}$ \\
\hline Dascyllus aruanus & Lagoon & Corals $(\mathrm{O})$ & $1-12$ & Small social group, No & $\mathrm{CS}$ \\
\hline Pomacentrus pavo & Lagoon & Corals (F) & $1-16$ & Small shoals, No & $\mathrm{CS}$ \\
\hline Stegastes nigricans & Lagoon & Dead corals/rocks & $1-12$ & Solitary, Yes & OS \\
\hline Chromis iomelas & Both & Corals $(\mathrm{F})$ & $3-35$ & Large shoals, No & $\mathrm{CS}$ \\
\hline Chromis margaritifer & Both & Corals (F) & $2-20$ & Large shoals, No & $\mathrm{CS}$ \\
\hline Dascyllus trimaculatus & Both & Corals (F) & $1-55$ & Medium shoals, No & FS \\
\hline Dascyllus flavicaudus & Both & Corals (F) & $3-40$ & Medium shoals, No & $\mathrm{CS}$ \\
\hline Chromis acares & Outer reef & Corals (F) & $2-37$ & Large shoals, No & $\mathrm{CS}$ \\
\hline Chromis vanderbilti & Outer reef & Corals (F) & $2-20$ & Large shoals, No & $\mathrm{CS}$ \\
\hline Plectroglyphidodon johnstonianus & Outer reef & Corals $(\mathrm{O})$ & $2-20$ & Solitary, Yes & OS \\
\hline Plectroglyphidodon lacrymatus & Outer reef & Dead corals/rocks & $2-12$ & Solitary, Yes & OS \\
\hline Pomachromis fuscidorsalis & Outer reef & Corals (F) & $1-20$ & Large shoals, No & OS \\
\hline Stegastes fasciolatus & Outer reef & Dead corals/rocks & $0-5$ & Solitary, Yes & OS \\
\hline
\end{tabular}

Species were classified according to their predominant (though not necessarily exclusive) ecological features. The reef location indicates where individuals were caught: lagoon, outer reef or both (lagoon and outer reef). Microhabitat requirements are "Sandy areas", "Corals" (coral-dwelling species, further divided into those that are obligate $(\mathrm{O})$ or facultative $(\mathrm{F})$ coral dwellers) and "Dead corals/rocks". The group type and territoriality were coded together. The depth range represents the minimal and the maximal depths expressed in metres. The position in the water column was coded as "FS" for freely swimmers, "CS" for species staying close to the substrate at a distance of $0.5-1.0 \mathrm{~m}$ and "OS" for species staying on the substrate all the time. ${ }^{\mathrm{a}}$ Information were completed with Pratchett et al. (2016), ${ }^{\mathrm{b}}$ with Hattori and Casadevall (2016) and ${ }^{\mathrm{c}}$ with Fishelson (1998)

differences among species revealed the presence of three groups (Kruskal-Wallis test, $H_{11}=94.45, P<0.001$; Supplementary Table S4; Fig. 3a). The first group consisted of lagoonal individuals from the four ubiquitous species (two Chromis spp. and two Dascyllus spp.) and the second group comprised A. sexfasciatus, $C$. viridis and $P$. pavo. Finally, the third group included the same species of Group 3.

Significant differences among damselfish species were also found according to their $\delta^{34} \mathrm{~S}$ values (Kruskal-Wallis test, $\left.H_{20}=153.64, P<0.001\right)$. Post hoc tests delineated three main groups (referred to as groups i, ii, and iii; Supplementary Table S5, Fig. 3b), which were further assessed by results of the dendrogram (Supplementary Fig. S3). $\delta^{34} \mathrm{~S}$ values highlighted a segregation between damselfish species from the outer reef and those from the lagoon (Fig. 3b). Group i consisted of five species exclusively caught on the outer reef ( $C$. acares, $C$. vanderbilti, $P$. fuscidorsalis, $P$. lacrymatus and $P$. johnstonianus), individuals from the outer reef of four ubiquitous species (C. iomelas, C. margaritifer, D. flavicaudus and D. trimaculatus) and finally comprised lagoonal individuals belonging to $C$. iomelas and $C$. margaritifer. Group ii included five species all from the lagoon (A. sexfasciatus, $C$. viridis, C. brownriggii, $P$. pavo and $S$. nigricans) and lagoonal assemblages of $D$. flavicaudus and D. trimaculatus. But it also comprised one species ( $S$. fasciolatus) from the outer reef. Finally, Group iii encompassed two lagoonal species, A. septemfasciatus (from Haapiti and Opunohu) and D. aruanus.

\section{Diversity of habitat and social behaviour}

Data regarding habitat and social behaviour are summarized in Table 2. Seven species were exclusively caught in the lagoon. Five of them were gregarious or found in pairs and the other two ( $C$. brownriggii and $S$. nigricans) presented a solitary behaviour. They were mostly living above 12-16 $\mathrm{m}$ depth; however, A. septemfasciatus and $C$. brownriggii were not encountered below 2-3 $\mathrm{m}$. The two Abudefduf sp. were freely swimming in the water column, while $C$. viridis, $C$. brownriggii, D. aruanus and $P$. pavo were staying close to the bottom at a distance of $0.5-1.0 \mathrm{~m}$. A majority of these species were found above various types of substrate even though $D$. aruanus and $C$. viridis were mainly foraging within live, branching corals. Abudefduf septemfasciatus was the only species found in sandy areas in between coral reef patches, and $S$. nigricans had its shelter in dead corals or rocks. Four species (C. iomelas, C. margaritifer, D. trimaculatus 
and D. flavicaudus) were ubiquitous and non-territorial. They were all facultative coral-dwelling species forming medium to large shoals in maximum depths of 20 to $55 \mathrm{~m}$. Only $D$. trimaculatus was observed to freely swim through the entire water column. Finally, the six remaining species exclusively foraged in the outer reef. Three of them (C. acares, $C$. vanderbilti and $P$. fuscidorsalis) were gregarious and facultative coral dwellers but staying close to the substrate at maximal depths of $20-37 \mathrm{~m}$. The three last species (P. johnstonianus, P. lacrymatus and $S$. fasciolatus) were solitary and exhibited a territorial behaviour. Plectroglyphidodon johnstonianus was found deeper than the two other species and was also more restricted into the type of substrate (i.e. live corals).

\section{Relationship between diet, habitat and social behaviour}

Standard multivariate linear regressions revealed significant relationships between trophic data, defined either by stomach contents (SC) or by stable isotopes (SI), and habitat-behaviour information. These correlations were further confirmed when integrating the phylogenetic relationships among species using the D-PGLS analysis (Table 3).

\section{Phylogenetic signals of ecological traits}

Both stomach contents $\left(K_{\text {mult }}=1.40, P=9 \times 10^{-4}\right)$ and habitat-behaviour information $\left(K_{\text {mult }}=1.17\right.$, $P=1 \times 10^{-4}$ ) showed significant phylogenetic signals. On the other hand, trophic data from stable isotopes did not present any phylogenetic signals $\left(K_{\text {mult }}=0.65, P=0.22\right)$.

\section{Discussion}

\section{Trophic ecology of damselfishes in Moorea}

At Toliara reef in Madagascar, Frédérich et al. (2009) defined three trophic groups of damselfishes, i.e. pelagic feeders, benthic feeders and an intermediate group. A similar level of trophic diversity is observed within the Pomacentridae from Moorea. The principal criterion used to differentiate the pelagic feeders from other trophic strategies is their propensity to almost exclusively feed on zooplanktonic prey (Frédérich et al. 2016b). Based on our dual dietary tracers $(\mathrm{C}, \mathrm{N}$ isotope ratios and stomach contents), seven species are representative of this trophic strategy. Three of them (C. acares, $C$. vanderbilti and $P$. fuscidorsalis) are only foraging in the outer reef, whereas the other four species (C. iomelas, C. margaritifer, D. flavicaudus and $D$. trimaculatus) also have individuals distributed in lagoonal zones close to the reef crest. As previously suggested by Wyatt et al. (2012), zooplanktivory is more common in
Table 3 Results of standard multivariate linear regression and D-PGLS (multidimensional phylogenetic regression least squares) tests applied on the 17 damselfish species from Moorea (collected in 2014) to test the degree of association between the two-dimensional (2D) space of trophic data (either obtained with stomach content (SC) or with stable isotope (SI) analyses) and the 2D space depicting habitat-behaviour information

Standard multivariate linear regres- $\quad$ D-PGLS analysis (with physion analysis (without phylogeny) logeny)

\begin{tabular}{lllllll}
\hline$F$ & $R^{2}$ & $P$ value & & $F$ & $R^{2}$ & $P$ value \\
\hline 2D space of $S C$ & versus & $2 D$ space of & habitat-behaviour & \\
17.19 & 0.71 & $2 \times 10^{-4}$ & & 4.84 & 0.44 & 0.01 \\
2D space of $S I$ versus & $2 D$ space of & habitat-behaviour & \\
17.04 & 0.71 & $1 \times 10^{-5}$ & 15.71 & 0.69 & $6 \times 10^{-6}$ \\
\hline
\end{tabular}

areas in proximity with the open ocean probably because of its constant input of water column-based plankton.

Benthic feeders include algivorous and corallivorous species and also damselfish species that mainly eat small benthic invertebrates. Both trophic markers reveal that six species (A. septemfasciatus, C. brownriggii, P. johnstonianus, $P$. lacrymatus, $S$. fasciolatus and $S$. nigricans) belong to this trophic group. Contrary to the zooplanktivorous species, benthic feeders are found across the whole coral reef ecosystem in Moorea, i.e. from the beach shore to the outer reef. Even though benthic algae were the main food items for P. johnstonianus at Moorea, other studies suggest that this species might be able to bite coral polyps (Allen 1991; Kuo and Shao 1991; Ho et al. 2009).

Frédérich et al. (2009) also defined an intermediate trophic group for which the types and origins of prey are diverse. In Moorea, four species belong to this feeding strategy: P. pavo, C. viridis, A. sexfasciatus and D. aruanus. Stomach contents reveal that $P$. pavo and $C$. viridis mainly feed on zooplankton but also ingest benthic algae and invertebrates (Fig. 2), which is confirmed by their $\delta^{13} \mathrm{C}$ and $\delta^{15} \mathrm{~N}$ values (Fig. 3a). Both species are not only chasing zooplankton but also supplement their diet with local, benthic prey. Trophic markers $(\mathrm{C}$ and $\mathrm{N}$ isotope ratios and stomach contents) provide evidence of omnivory in A. sexfasciatus. At Toliara reef, A. sexfasciatus was exclusively feeding on zooplankton (Frédérich et al. 2009), while the feeding regime of populations from Seychelles was classified as intermediate (Manica 2002). This geographic variation among populations supports trophic opportunism in $A$. sexfasciatus. Finally, D. aruanus also shows a dietary plasticity as this species feeds on planktonic prey and benthic algae in (almost) equal proportions, and its isotope ratios for $\mathrm{C}$ and $\mathrm{N}$ are very distinct (Fig. 3a). Frédérich et al. (2010) found a gradual shift of foraging tactics related to the size of $D$. aruanus, with smaller individuals depending more on food sources from the benthic compartment 


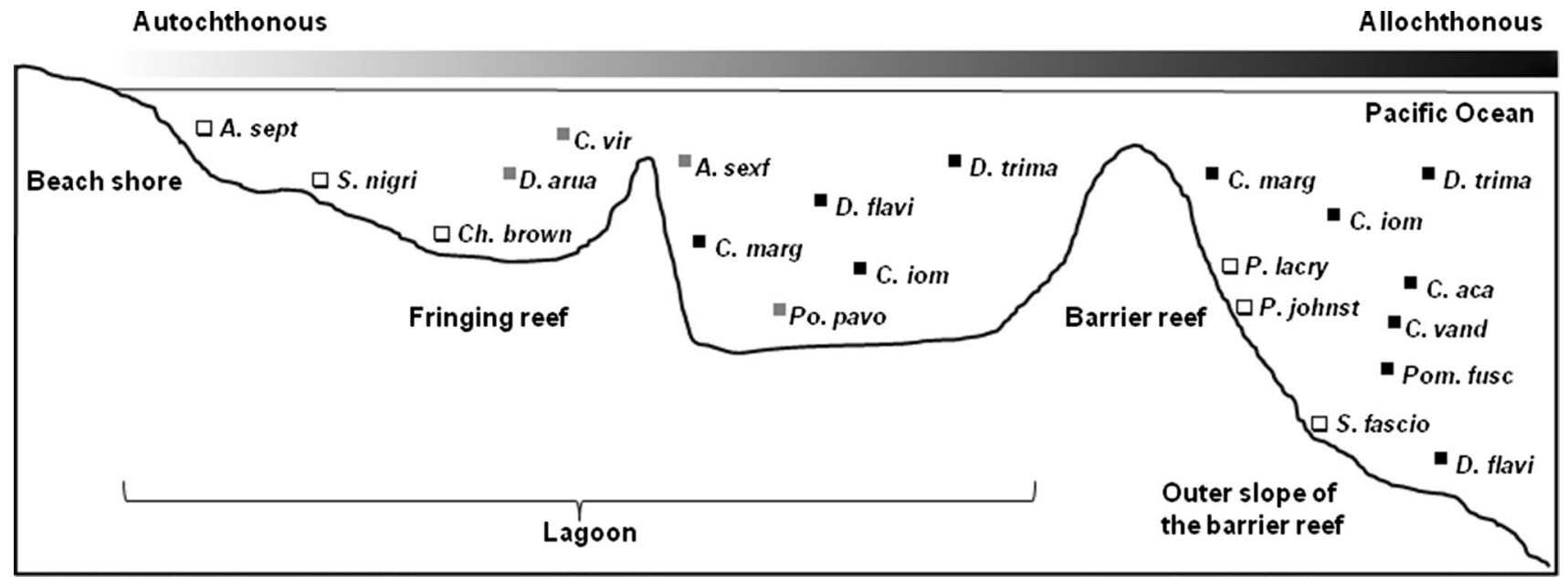

Fig. 4 Position of damselfish species along a schematic representation of the coral reef ecosystem in Moorea, French Polynesia. Species abbreviations are found in Table 1. Trophic groups are represented by white-filled squares for "benthic feeders", grey-filled squares for "intermediate group" and black-filled squares for "pelagic feeders".

and, with larger ones mainly feeding on pelagic prey. The sampled $D$. aruanus in our study differed in length (29.8-47.3 mm; Table 1), and thus the large diet breadth in Moorea could also be related to size variation.

\section{Dietary cross-reef gradient}

Research devoted to the study of variations in trophodynamics remain scarce, especially for coral reef ecosystems (see exceptions in Kolasinski et al. 2009; Greenwood et al. 2010; Wyatt et al. 2012; Davis et al. 2014; Hanson et al. 2016). The coral reef ecosystem of Moorea presents a complex topography, including a protected lagoon with many coral patches, a fringing reef shaped as a wall, and a barrier reef with a crest bounding the open ocean (Fig. 4). The influence of these morphological features on the trophic ecology of Pomacentridae is emphasized by the significant differences in $\mathrm{S}$ isotope ratios among species. Indeed, $\delta^{34} \mathrm{~S}$ has been used to unravel food sources for mobile consumers (Jardine et al. 2012) and to ascertain within-producer variability (Connolly et al. 2004; Hamilton 2009; Mittermayr et al. 2014). Pelagic producers using seawater sulphates $\left(\sim 22.9 \%\right.$ o) have higher $\delta^{34} \mathrm{~S}$ values, whereas consumers depending on sulphur from sediments $\left(\sim 1 \%\right.$ o) have lower $\delta^{34} \mathrm{~S}$ values (Kharlamenko et al. 2001; Connolly et al. 2004). Consequently, $\delta^{34} \mathrm{~S}$ values help to discriminate between organisms feeding on prey from the pelagic compartment and the others relying on food from the benthos. Here, the $\delta^{34} \mathrm{~S}$ results revealed that the assemblage of damselfishes from the outer reef (Group i) can be segregated from the pomacentrid assemblage (Group ii, iii) present in the protected lagoon (Fig. 3b). The diet of
The gradient from white to black colour indicates the degree of reliance on food sources from an autochthonous/locally produced origin towards an allochthonous/oceanic provenance. The axes are not to scale

Group $i$ is mainly dependent on oceanic productivity and its subsequent input of planktonic prey. On the other hand, $\delta^{34} \mathrm{~S}$ values of Group ii show a higher reliance on local, autochthonous resources (filamentous algae and vagile invertebrates). The species, A. septemfasciatus, belonging to Group iii reinforces this dietary gradient across the coral reefs along the coastline at Moorea. This species uniquely forages above sandy banks surrounded by coral patches next to the beach shore. The low $\delta^{34} \mathrm{~S}$ value observed in A. septemfasciatus is probably related to insects found in their stomachs, indicating a dietary dependence on terrestrial input. The ingress of water column-based phytoplankton in the coral reef food-web is not restricted to zones in permanent contact or close to the open ocean, but is rather progressively distributed. This hypothesis is sustained by findings of two studies conducted, respectively, on the pelagic feeder D. flavicaudus (Hanson et al. 2016) and on the benthic feeder S. nigricans (McMahon et al. 2016). Results on D. flavicaudus, also collected within the Opunohu Bay in Moorea, revealed that this species actively selects oceanic copepods irrespective of the fish position in the reef (lagoon versus outer reef; Hanson et al. 2016). In spite of its foraging area in shallow lagoonal waters and its benthic dietary specialization, Stegastes nigricans still partially assimilates $\mathrm{C}$ from oceanic sources (McMahon et al. 2016). Overall, the trophic ecology of damselfishes in Moorea is intrinsically linked to their locations within the reef ecosystem. The trophic strategies reflect the influx of oceanic-derived plankton and its assimilation by the reef food-web. The majority of pelagic feeders is found in areas closer to the open ocean or outside the reef system, all benthic feeders are ubiquitous and the intermediate 
feeding strategy is only present in the protected lagoon (Fig. 4).

\section{The relationships between diet, habitat and social behaviour}

Previous studies about damselfishes carried out in Florida and Madagascar have suggested that diet, habitat and social behaviour could be correlated (Emery 1973; Frédérich et al. 2009). Here, we quantitatively demonstrate a tight association between these ecological variables in the damselfish community from Moorea. We further confirm these correlations when the phylogenetic relatedness among damselfish species is integrated. Almost all pelagic feeders (i.e. 4 Chromis spp. and 2 Dascyllus spp.) are found within the Chrominae subfamily (Fig. 5), except for P. fuscidorsalis. They exhibit similar social behaviours forming large aggregations (either shoals or schools) up to $20 \mathrm{~m}$ depth and live in areas bathed by the open ocean or just behind the barrier reef crest. They are also associated with either live or dead corals. The second most species-rich guild in Moorea is the benthic feeders, and within that group, four species belong to the Stegastinae subfamily (i.e. 2 Stegastes spp. and 2 Plectroglyphidon spp.). In contrast to pelagic feeders, benthic feeders mostly display a territorial, solitary behaviour, and they can establish their shelter on other types of substrate than corals. Only, P. johnstonianus forages among branches of live corals. Stegastes nigricans and P. lacrymatus are able to harvest macroalgal lawn like farmers (Hata and Makoto 2002; Ceccarelli et al. 2005). The last trophic strategy-the intermediate group-is represented by $A$. sexfasciatus in the Abudefdufinae, $P$. pavo in the Pomacentrinae and $C$. viridis and $D$. aruanus in the Chrominae. Species from the intermediate group are all gregarious, but only forage in the protected lagoon at usually shallower depths than pelagic feeders. Two of them $(C$. viridis and $D$. aruanus) are obligate inhabitants of live corals.

\section{Ecological trait conservatism and community structure}

Diet, defined with stomach contents, presents a phylogenetic signal suggesting some conservatism through the evolution of damselfish communities. We also provide some evidence of conservatism for the behaviour which seems, therefore, less labile than previously thought (Blomberg et al. 2003). Contrary to the study of Blomberg et al. (2003), we coded this character with ecological information and created a unique multivariate trait called "habitat-behaviour". This combination of traits delineates a high level of habitat and behavioural diversity which appears relatively conserved through the evolution of damselfishes. In general, the causes of conservatism and PNC patterns are diverse, can interact with one another and produce complex outcomes (Revell et al. 2008; Crisp and Cook 2012). They include both direct (e.g. heritability, selection) and indirect processes (e.g. antagonistic niche interactions or dispersal opportunity) (Crisp and Cook 2012). Here, closely related pomacentrid species feed on the same types of prey and exhibit similar habitat features and social behaviours (e.g. Stegastinae and Chrominae). Thus, this
Fig. 5 Consensus timecalibrated tree illustrating the three dietary strategies for the 17 damselfish species from Moorea and with indication of the subfamilies. Trophic groups are represented by white-filled squares for "benthic feeders", grey-filled squares for "intermediate group" and black-filled squares for "pelagic feeders"

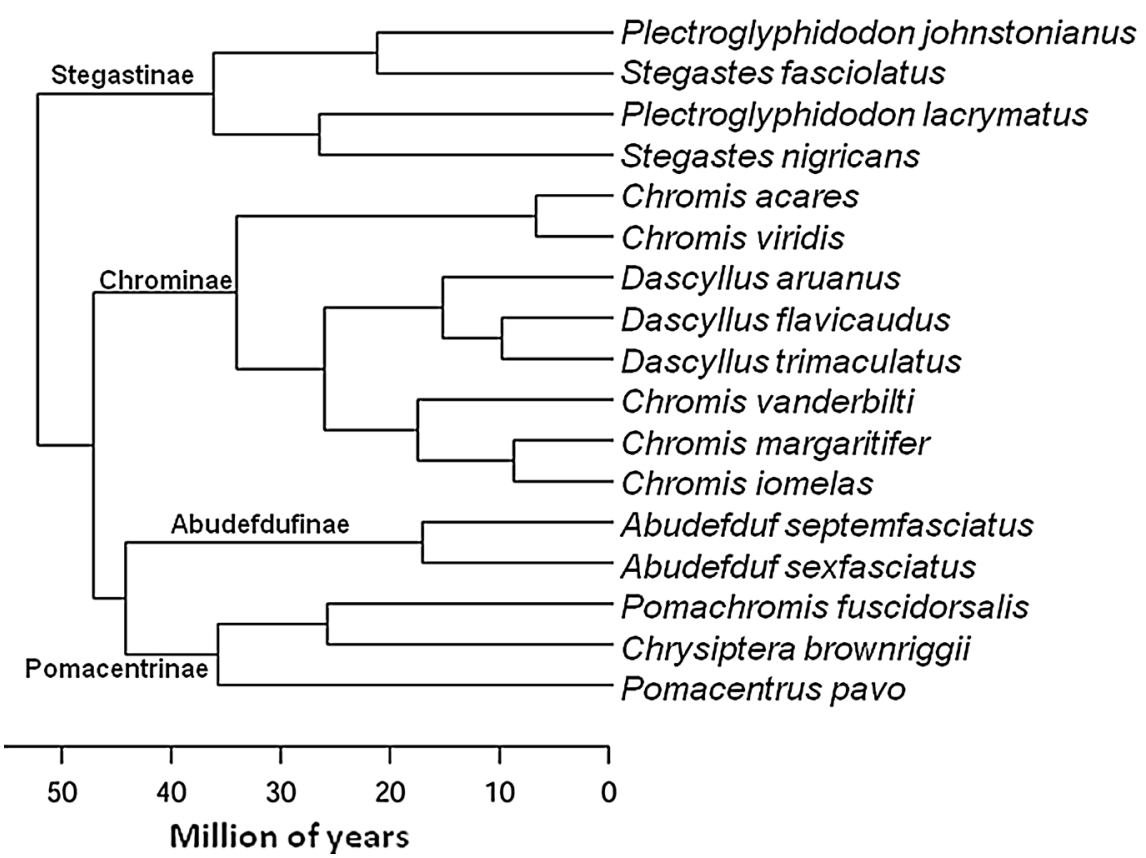


ecological resemblance seems to be greater than expected under a Brownian motion model of evolution. In agreement with the concept of niche retention (Cooper et al. 2010), damselfish lineages could have somehow inherited these characters from their ancestors and slowly diverged. This equivalency might also arise from stabilizing selection and constraints (Cooper et al. 2010; Crisp and Cook 2012). A higher dietary specialization (primarily feeding on one particular type of prey), a narrowing of the habitat-behaviour niche (a partial exploitation of the core species niche) and a limitation of larval dispersal opportunities (induced by physical barrier) are among the possible constraints which could generate a PNC pattern for the stomach content and the habitat-behaviour traits.

Interestingly, trophic specializations defined by the CNS isotope ratios are evolutionarily more labile than diet from stomach contents. The greater malleability of isotopic trait over macroevolutionary time is probably due to its complex signature which embodies more facets of ecological niches (i.e. the dietary, habitat and behavioural components) and over a long period of time, from weeks to months (Tieszen et al. 1983). The $\mathrm{C}$ and $\mathrm{N}$ isotope ratios are primarily proxies of trophic ecology (i.e. type of prey, foraging location) but may also reflect internal physiological changes during special events such as ontogeny, metamorphosis, starvation or even pregnancy (e.g. Habran et al. 2010; Hammerschlag-Peyer et al. 2011; Frédérich et al. 2012; Gajdzik et al. 2015). Furthermore, the $S$ isotope ratios mostly reflect the fish position within the reef-scape (lagoon versus outer reef) and the partitioning of microhabitats within each reef zone (pelagic versus benthic compartments). Isotopic data integrate several types of biological information (including ecology and physiology), which might curb the phylogenetic signal of the isotopic trait during the evolution of lineages. The lack of evidence of PNC pattern for the isotopic trait, in contrast to the pattern of stomach content data, suggests that the true diet (a combination of these two techniques) of damselfishes could not be so well matched to the phylogeny.

Furthermore, detecting a phylogenetic signal is contextdependent and influenced by many factors (Losos 2008). Indeed, the signal of a subset of species, such as the studied community of damselfishes, may differ from the one for more inclusive groups (Losos 2008). At the family level, damselfishes observed a macroevolutionary pattern made of iterative ecological radiation and convergences (Frédérich et al. 2013, 2016a). Our results illustrate that this particular process of diversification has produced communities in which closely related species are more ecologically similar than expected by chance. This outcome differs from the case of Anolis lizards, where ecological similarity and phylogenetic relatedness is very weak (Losos et al. 2003). These contrasting results from two old radiations ( $>15-20$ million years ago) suggest that community evolution may occur in different, complex ways. Here, the phylogenetic signals detected may reflect the prevalence of geographic settings producing ecologically similar species during the evolutionary genesis of damselfish community structure.

\section{Conclusion}

The trophic ecology of damselfishes in Moorea reveals two opposing trophic strategies: pelagic feeders depending on water column-derived zooplankton and benthic feeders relying on food (algae and vagile invertebrates) from the benthos. In between, there are species displaying different degrees of food exploitation throughout the whole bentho-pelagic compartment. Sulphur isotope ratios show a gradient across the coral reef ecosystem, from a system mostly relying on oceanic support (i.e. the outer reef) towards a system more dependent on autochthonous local productivity (i.e. the lagoon). We demonstrate a tight association between dietary, habitat and behavioural traits in the community of damselfishes from Moorea. Diet defined by stomach contents and habitat-behaviour are conserved through evolution of damselfishes. On the other hand, the isotopic trait is evolutionarily more labile probably because it is affected by a complex array of factors related to diet, habitat and physiology. Further studies focusing on other clades of reef fishes and including other damselfish communities from various regions would improve our understanding of the processes shaping the assembly of fish community in the coral reef ecosystem.

Acknowledgements L.G. and N.S. are, respectively, a Research Fellow and a Research Logistic Collaborator of the National Fund for Scientific Research of Belgium (F.R.S-FNRS). B.F. is a postdoctoral researcher at the Belgian Science Policy Office (BELSPO). We would like to thank Serge Planes, David Lecchini, Frank Rouvreur, Lauric Thiault and Ewen Morin (CRIOBE, Moorea, French Polynesia) for providing hospitality, laboratory facilities and help during fieldwork. This research was supported by a Grant from F.R.S-FNRS (contract no. 24880335) and complemented by a subvention from the "Concours de bourse de voyage 2014" of the Wallonia-Brussels Federation.

\section{Compliance with ethical standards}

Conflict of interest The authors declare that they have no conflict of interest.

Informed consent Informed consent was obtained from all individual participants included in the study.

Human and animals rights All applicable international, national, and/or institutional guidelines for the care and use of animals were followed. 


\section{References}

Adams DC (2014a) A generalized K statistic for estimating phylogenetic signal from shape and other high-dimensional multivariate data. Syst Biol 63:685-697. doi:10.1093/sysbio/syu030

Adams DC (2014b) A method for assessing phylogenetic least squares models for shape and other high-dimensional data. Evolution 68:2675-2688. doi:10.1111/evo.12463

Adams DC, Otárola-Castillo E (2013) geomorph: an R package for the collection and analysis of geometric morphometric shape data. Methods Ecol Evol 4:393-399. doi:10.1111/2041-210X.12035

Alfaro ME, Santini F, Brock CD (2007) Do reefs drive diversification in marine teleosts? Evidence from the pufferfish and their allies (Order Tetraodontiformes). Evolution 61:2104-2126. doi:10.1111/j.1558-5646.2007.00182.x

Allen GR (1991) Damselfishes of the world. Mergus, Germany

Blomberg SP, Garland T, Ives AR (2003) Testing for phylogenetic signal in comparative data: behavioral traits are more labile. Evolution 57:717-745. doi:10.1111/j.0014-3820.2003.tb00285.x

Cailliez F (1983) The analytical solution of the additive constant problem. Psychometrika 48:305-308. doi:10.1007/BF02294026

Cavender-Bares J, Kozak KH, Fine PVA, Kembel SW (2009) The merging of community ecology and phylogenetic biology. Ecol Lett 12:693-715. doi:10.1111/j.1461-0248.2009.01314.x

Ceccarelli DM, Jones GP, McCook LJ (2005) Foragers versus farmers: contrasting effects of two behavioural groups of herbivores on coral reefs. Oecologia 145:445-453. doi:10.1007/s00442-005-0144-y

Clarke KR (1993) Non-parametric multivariate analyses of changes in community structure. Aust Ecol 18:117-143. doi:10.1111/j.1442-9993.1993.tb00438.x

Collyer ML, Sekora DJ, Adams DC (2015) A method for analysis of phenotypic change for phenotypes described by high-dimensional data. Heredity 115:357-365. doi:10.1038/hdy.2014.75

Colwell RK, Fuentes ER (1975) Experimental studies of the niche. Annu Rev Ecol Syst 6:281-310. doi:10.1146/annurev. es.06.110175.001433

Connolly RM, Guest MA, Melville AJ, Oakes JM (2004) Sulfur stable isotopes separate producers in marine food-web analysis. Oecologia 138:161-167. doi:10.1007/s00442-003-1415-0

Cooper WJ, Santini F (2016) A revised damselfish taxonomy with a description of the tribe Microspathodontini (Giant damselfishes). In: Frédérich B, Parmentier E (eds) Biology of damselfishes. CRC Press, Boca Raton, pp 13-30

Cooper WJ, Westneat MW (2009) Form and function of damselfish skulls: rapid and repeated evolution into a limited number of trophic niches. BMC Evol Biol 9:24

Cooper WJ, Smith LL, Westneat MW (2009) Exploring the radiation of a diverse reef fish family: phylogenetics of the damselfishes (Pomacentridae), with new classifications based on molecular analyses of all genera. Mol Phylogenet Evol 52:1-16. doi:10.1016/j.ympev.2008.12.010

Cooper N, Jetz W, Freckleton RP (2010) Phylogenetic comparative approaches for studying niche conservatism. J Evol Biol 23:2529-2539. doi:10.1111/j.1420-9101.2010.02144.x

Cooper N, Freckleton RP, Jetz W (2011) Phylogenetic conservatism of environmental niches in mammals. Proc R Soc B Biol Sci 278:2384-2391. doi:10.1098/rspb.2010.2207

Coplen TB (2011) Guidelines and recommended terms for expression of stable-isotope-ratio and gas-ratio measurement results. Rapid Commun Mass Spectrom 25:2538-2560. doi:10.1002/rcm.5129

Crisp MD, Cook LG (2012) Phylogenetic niche conservatism: what are the underlying evolutionary and ecological causes? New Phytol 196:681-694. doi:10.1111/j.1469-8137.2012.04298.x

Davis J (1986) Statistics and data analysis in geology, 2nd edn. Wiley, New York, p 550
Davis JP, Pitt KA, Fry B et al (2014) Seascape-scale trophic links for fish on inshore coral reefs. Coral Reefs 33:897-907. doi:10.1007/ s00338-014-1196-4

Emery AR (1973) Comparative ecology and functional osteology of fourteen species of damselfish (Pisces: Pomacentridae) at Alligator Reef. Florida Keys. Bull Mar Sci 23:649-770

Eschmeyer WN, Fricke R, van der Laan R (eds) (2016) Catalog of fishes: genera, species, references. (http://researcharchive. calacademy.org/research/ichthyology/catalog/fishcatmain.asp). Accessed 18 Aug 2016

Fishelson L (1998) Behaviour, socioecology and sexuality in damselfishes (Pomacentridae). Ital J Zool 65:387-398. doi:10.1080/11250009809386853

Frédérich B, Fabri G, Lepoint G et al (2009) Trophic niches of thirteen damselfishes (Pomacentridae) at the Grand Récif of Toliara, Madagascar. Ichthyol Res 56:10-17. doi:10.1007/ s10228-008-0053-2

Frédérich B, Lehanse O, Vandewalle P, Lepoint G (2010) Trophic niche width, shift, and specialization of Dascyllus aruanus in Toliara lagoon, Madagascar. Copeia 2010:218-226. doi:10.1643/CE-09-031

Frédérich B, Colleye O, Lepoint G, Lecchini D (2012) Mismatch between shape changes and ecological shifts during the post-settlement growth of the surgeonfish, Acanthurus triostegus. Front Zool 9:8. doi:10.1186/1742-9994-9-8

Frédérich B, Sorenson L, Santini F et al (2013) Iterative ecological radiation and convergence during the evolutionary history of damselfishes (Pomacentridae). Am Nat 181:94-113. doi:10.1086/668599

Frédérich B, Cooper WJ, Aguilar-Medrano R (2016a) Ecomorphology and iterative ecological radiation of damselfishes. In: Frédérich B, Parmentier E (eds) Biology of damselfishes. CRC Press, Boca Raton, pp 183-203

Frédérich B, Olivier D, Gajdzik L, Parmentier E (2016b) Trophic ecology of damselfishes. In: Frédérich B, Parmentier E (eds) Biology of damselfishes. CRC Press, Boca Raton, pp 153-167

Fry B, Cieri M, Hughes J et al (2008) Stable isotope monitoring of benthic-planktonic coupling using salt marsh fish. Mar Ecol Prog Ser 369:193-204. doi:10.3354/meps07644

Gajdzik L, Lepoint G, Lecchini D, Frédérich B (2015) Comparison of isotopic turnover dynamics in two different muscles of a coral reef fish during the settlement phase. Sci Mar 79:325-333. doi:10.3989/scimar.04225.31A

Goslee SC, Urban DL (2007) The ecodist package for dissimilarity-based analysis of ecological data. J Stat Softw 22:1-19. doi:10.18637/jss.v022.i07

Gower JC (1971) A general coefficient of similarity and some of its properties. Biometrics 27:857. doi:10.2307/2528823

Greenwood NDW, Sweeting CJ, Polunin NVC (2010) Elucidating the trophodynamics of four coral reef fishes of the Solomon Islands using $\delta^{15} \mathrm{~N}$ and $\delta^{13} \mathrm{C}$. Coral Reefs 29:785-792. doi:10.1007/ s00338-010-0626-1

Habran S, Debier C, Crocker DE et al (2010) Assessment of gestation, lactation and fasting on stable isotope ratios in northern elephant seals (Mirounga angustirostris). Mar Mamm Sci 26:880-895. doi:10.1111/j.1748-7692.2010.00372.x

Hamilton SK (2009) Stable isotopes in ecology and environmental science. J N Am Benthol Soc 28:516. doi:10.1899/0887-3593-028.002.0516

Hammerschlag-Peyer CM, Yeager LA, Araújo MS, Layman CA (2011) A hypothesis-testing framework for studies investigating ontogenetic niche shifts using stable isotope ratios. PLoS ONE 6:e27104. doi:10.1371/journal.pone.0027104

Hanson KM, Schnarr EL, Leichter JJ (2016) Non-random feeding enhances the contribution of oceanic zooplankton to the diet of the planktivorous coral reef fish Dascyllus flavicaudus. Mar Biol 163:77. doi:10.1007/s00227-016-2849-3 
Hata H, Makoto K (2002) Weeding by the herbivorous damselfish Stegastes nigricans in nearly monocultural algae farms. Mar Ecol Prog Ser 237:227-231

Hattori A, Casadevall M (2016) Sex change strategies and group structure of damselfishes. In: Parmentier E, Frédérich B (eds) Biology of damselfishes. CRC Press, Boca Raton, pp 55-82

Ho C, Fu Y, Sun C et al (2009) Plasticity of feeding habits of two Plectroglyphidodon damselfishes on coral reefs in Southern Taiwan: evidence from stomach content and stable isotope analyses. Zool Stud 48:649-656

Hyslop EJ (1980) Stomach contents analysis-a review of methods and their application. J Fish Biol 17:411-429. doi:10.1111/j.1095-8649.1980.tb02775.x

Jardine TD, Pusey BJ, Hamilton SK et al (2012) Fish mediate high food web connectivity in the lower reaches of a tropical floodplain river. Oecologia 168:829-838. doi:10.1007/ s00442-011-2148-0

Kharlamenko V, Kiyashko S, Imbs A, Vyshkvartzev D (2001) Identification of food sources of invertebrates from the seagrass Zostera marina community using carbon and sulfur stable isotope ratio and fatty acid analyses. Mar Ecol Prog Ser 220:103-117. doi:10.3354/meps220103

Knouft JH, Losos JB, Glor RE, Kolbe JJ (2006) Phylogenetic analysis of the evolution of the niche in lizards of the Anolis sagrei group. Ecology 87:S29-S38

Kolasinski J, Frouin P, Sallon A et al (2009) Feeding ecology and ontogenetic dietary shift of yellowstripe goatfish Mulloidichthys flavolineatus (Mullidae) at Reunion Island, SW Indian Ocean. Mar Ecol Prog Ser 386:181-195. doi:10.3354/meps08081

Kuo S, Shao K (1991) Feeding habits of damselfishes (Pomacentridae) from the southern part of Taiwan. J Fish Soc Taiwan 18:165-176

Lecchini D, Galzin R (2005) Spatial repartition and ontogenetic shifts in habitat use by coral reef fishes (Moorea, French Polynesia). Mar Biol 147:47-58. doi:10.1007/s00227-004-1543-Z

Legendre P, Legendre L (1998) Numerical ecology. Elsevier, Philadelphia

Losos JB (2008) Phylogenetic niche conservatism, phylogenetic signal and the relationship between phylogenetic relatedness and ecological similarity among species. Ecol Lett 11:995-1003. doi:10.1111/j.1461-0248.2008.01229.x

Losos JB, Leal M, Glor RE et al (2003) Niche lability in the evolution of a Caribbean lizard community. Nature 424:542-545. doi:10.1038/nature01814

Maechler M, Rousseeuw P, Struyf A et al (2015) Cluster: cluster analysis basics and extensions. R Package version 2.0.4

Maire E, Grenouillet G, Brosse S, Villéger S (2015) How many dimensions are needed to accurately assess functional diversity? A pragmatic approach for assessing the quality of functional spaces. Glob Ecol Biogeogr 24:728-740. doi:10.1111/geb.12299

Manica A (2002) Alternative strategies for a father with a small brood: mate, cannibalise or care. Behav Ecol Sociobiol 51:319-323. doi:10.1007/s00265-001-0444-0

Mateo MA, Serrano O, Serrano L, Michener R (2008) Effects of sample preparation on stable isotope ratios of carbon and nitrogen in marine invertebrates: implications for food web studies using stable isotopes. Oecologia 157:105-115. doi:10.1007/ s00442-008-1052-8

McCutchan JH, Lewis WM, Kendall C, McGrath CC (2003) Variation in trophic shift for stable isotope ratios of carbon, nitrogen, and sulfur. Oikos 102:378-390. doi:10.1034/j.1600-0706.2003.12098.x

McMahon KW, Thorrold SR, Houghton LA, Berumen ML (2016) Tracing carbon flow through coral reef food webs using a compound-specific stable isotope approach. Oecologia 180:809821. doi:10.1007/s00442-015-3475-3

Mittermayr A, Fox S, Sommer U (2014) Temporal variation in stable isotope composition $(\delta 13 \mathrm{C}, \delta 15 \mathrm{~N}$ and $\delta 34 \mathrm{~S})$ of a temperate Zostera marina food web. Mar Ecol Prog Ser 505:95-105. doi:10.3354/meps 10797

Moreno R, Jover L, Munilla I et al (2010) A three-isotope approach to disentangling the diet of a generalist consumer: the yellow-legged gull in northwest Spain. Mar Biol 157:545-553. doi:10.1007/s00227-009-1340-9

Mouillot D, Villeger S, Parravicini V et al (2014) Functional overredundancy and high functional vulnerability in global fish faunas on tropical reefs. Proc Natl Acad Sci 111:13757-13762. doi:10.1073/pnas.1317625111

Ndiribe C, Salamin N, Guisan A (2013) Understanding the concepts of community phylogenetics. Evol Ecol Res 15:853-868

Newsome SD, Martinez del Rio C, Bearhop S, Phillips DL (2007) A niche for isotopic ecology. Front Ecol Environ 5:429-436. doi:10.1890/060150.01

Ormond RFG, Roberts JM, Jan RQ (1996) Behavioural differences in microhabitat use by damselfishes (Pomacentridae): implications for reef fish biodiversity. J Exp Mar Biol Ecol 202:85-95

Paradis E, Claude J, Strimmer K (2004) APE: analyses of phylogenetics and evolution in R language. Bioinformatics 20:289-290

Post DM (2002) Using stable isotopes to estimate trophic position: models, methods and assumptions. Ecology 83:703-718

Pratchett MS, Hoey AS, Wilson SK et al (2016) Habitat-use and specialisation among coral reef damselfishes. In: Frédérich B, Parmentier E (eds) Biology of damselfishes. CRC Press, Boca Raton, pp 84-121

Price SA, Holzman R, Near TJ, Wainwright PC (2011) Coral reefs promote the evolution of morphological diversity and ecological novelty in labrid fishes. Ecol Lett 14:462-469. doi:10.1111/j.1461-0248.2011.01607.x

R Core Team (2016) A language and environment for statistical computing. R Foundation for Statistical Computing, Vienna

Revell LJ (2012) phytools: an R package for phylogenetic comparative biology (and other things). Methods Ecol Evol 3:217-223

Revell L, Harmon L, Collar D (2008) Phylogenetic signal, evolutionary process, and rate. Syst Biol 57:591-601. doi:10.1080/10635150802302427

Revell LJ, Mahler DL, Reynolds RG, Slater GJ (2015) Placing cryptic, recently extinct, or hypothesized taxa into an ultrametric phylogeny using continuous character data: a case study with the lizard Anolis roosevelti. Evolution 69:1027-1035. doi:10.1111/evo.12628

Roy K, Hunt G, Jablonski D (2009) Phylogenetic conservatism of extinctions in marine bivalves. Science 325:733-737. doi: $10.1126 /$ science. 1173073

Schoener TW (1974) Resource partitioning in ecological communities. Science 185:27-39

Tieszen LL, Boutton TW, Tesdahl KG, Slade NA (1983) Fractionation and turnover of stable carbon isotopes in animal tissues: Implications for ${ }^{13} \mathrm{C}$ analysis of diet. Oecologia 57:32-37. doi:10.1007/ BF00379558

Webb CO, Ackerly DD, McPeek MA, Donoghue MJ (2002) Phylogenies and community ecology. Annu Rev Ecol Syst 33:475-505. doi:10.1146/annurev.ecolsys.33.010802.150448

Wyatt ASJ, Waite AM, Humphries S (2012) Stable isotope analysis reveals community-level variation in fish trophodynamics across a fringing coral reef. Coral Reefs 31:1029-1044. doi:10.1007/ s00338-012-0923-y 